\title{
Variability of hepatic a-amylase activities in the liver of fish species from the Sevastopol bays, Black Sea
}

\section{Natalya Kuzminova}

A. O. Kovalevsky Institute of Biology of the Southern Seas, Russian Academy of Sciences, Nakhimov Ave., 2, Sevastopol, 299011, Crimea, Russian Federation

Address correspondence and requests for materials to Natalya Kuzminova, kunast@rambler.ru

\begin{abstract}
This paper presents the results of a study of a-amylase activity in the liver of widely represented species of twelve Black Sea fish. Comparative analysis of interspecies differences showed that the medium level of enzyme activity is very high only in the liver of annular seabream and horse mackerel. The Black Sea carnivorous species (scorpion fish, stargazers, shore rockling and whiting) have low values of the medium level of enzyme activity (range from 0.02 to $62.79 \mathrm{mg} / \mathrm{s} / \mathrm{g}$ of protein). Enzyme activity did not depend on fish sex, their age or location. Research has established a lack of any link between enzyme activity and age for both the scorpion fish and high body pickerel. While studying the effects of seasonal peculiarities on enzyme activity in the liver of two dominant species in the coastal zone, it was concluded that enzyme activity is lower in winter than in other seasons.
\end{abstract}

Keywords: fish, digestive enzyme, liver, Black Sea.

\section{Introduction}

It is known that many researchers are turning to the analysis of biochemical parameters which are widely used in clinical biochemistry and veterinary medicine as indicators of fish health (Kuzmina, 1977; Pozdnyakova et al., 2009; Vinnikova, 2010; Afanasiev, 2011; Kuzminova, 2016) because reports with these indices are

Citation: Kuzminova, N. 2019. Variability of the hepatic a-amilase activities in the liver of fish species from the Sevastopol bays, Black Sea. Bio. Comm. 64(4): 235-243. https://doi. org/10.21638/spbu03.2019.402

Author's information: Natalya Kuzminova, PhD, Senior Researcher, orcid.org/00000001-5453-0136

Manuscript Editor: Anna Malashicheva, Almazov Federal Medical Research Centre, Saint Petersburg, Russia

Received: September 4, 2019;

Revised: November 17, 2019;

Accepted: November 20, 2019;

Copyright: (c) 2019 Kuzminova. This is an open-access article distributed under the terms of the License Agreement with Saint Petersburg State University, which permits to the authors unrestricted distribution, and self-archiving free of charge.

Funding: The work was carried out on the state theme of the IBSS "Molismological and Biogeochemical Basis of the Homeostasis of Marine Ecosystems" (№ 0828-2019-0006) (registration number: AAAA-A18-118020890090-2).

Competing interests: The authors have declared that no competing interests exist. very informative, and it is these parameters that almost immediately show a system's response to natural and anthropogenic changes.

It is obvious that digestive enzyme activity depends mainly on the formation of the digestive tract and feeding habits (Ugolev and Kuzmina, 1993; Gisbert et al. 2009; Zacarias-Soto Barón-Sevilla and Lazo, 2013; Umalatha, Kushwaha and Gangadhar, 2016); however, it is already known that the impact of xenobiotics and natural particular features of fish and water areas affect the level of their activity (Kandyuk, 1966; Ferreira, Field and Tuttle, 2010; Sadhu et al. 2014).

As far as Black Sea fish are concerned, such studies have been carried out previously on antioxidant enzymes and circulating immune complexes. It was found that the activation of protective systems is more pronounced in females at the high pollution level of Black Sea bays and in young and middle-aged individuals (Kuzminova, 2010; Rudneva, Kuzminova, Skuratovskaya and Kovyrshina, 2010; Kuzminova, Dorokhova and Rudneva, 2014a; Kuzminova, Kulakovskaya and Yakimova, 2014b). Therefore, it was interesting to analyze other biochemical parameters of the Black Sea fish with the aim of assessing their health and living conditions. The liver, as the main digestive gland and detoxification organ in this regard, is a suitable research material.

Amylase (diastase, 1,4- $\alpha$-D-glyukangidrolase, EC 3.2.1.1.) is an enzyme with a molecular weight in different organisms of $10-435 \mathrm{kDa}$ which is involved in the hydrolysis of the basic substance groups; it catalyzes hydrolysis of $\alpha$-1,4-glucosidic 


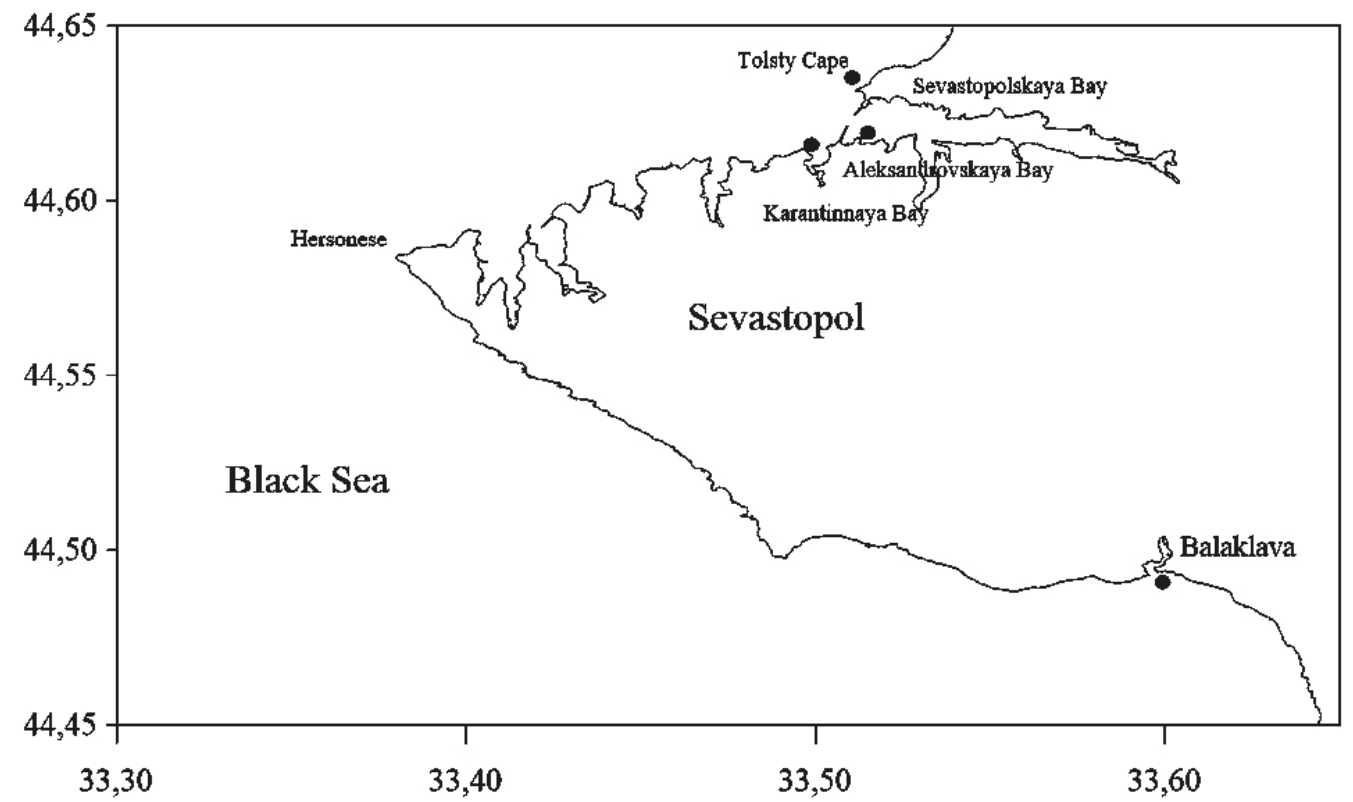

Fig. 1. Sampling sites in Sevastopol bays $\left(44^{\circ} 36^{\prime} \mathrm{N}-33^{\circ} 32^{\prime} \mathrm{E}\right.$, Sevastopol, Black Sea).

linkages of starch and glycogen into maltose and dextrins (https://www.brenda-enzymes.org/enzyme; http://www. worthington-biochem.com/AA/). Amylase molecular weight in fish is usually $55-57 \mathrm{kDa}$ (Moreau et al., 2001; Krogdahl et al., 2005;) and even more (100 kDa) (Alarcon, Martínez, Díaz and Moyano, 2001).

In fish, amylase acts throughout the gastrointestinal tract (Umalatha, Kushwaha and Gangadhar, 2016). The distribution pattern of amylase in the digestive tract mucosa can vary not only for different species and ecological groups, but also within a group of the same species (Ugolev and Kuzmina, 1993). It is known that with relatively constant seasonal activity, differences in the nature of the desorption characteristics were found. Findings on the link between enzyme activity and such factors as type of nutrition or the environmental group of marine or freshwater fish can be described as ambiguous, because there is some evidence that this enzyme has individual variability which depends on the topography of the intestine and, more importantly, there can be differences in groups of the same species living in different water areas, which are certainly determined by food source (Ugolev and Kuzmina, 1993).

Therefore, the aim of this research project was to analyze the variability of alpha-amylase activity in the liver of different species of Black Sea fish, with sex, age, species features, catch points and seasonal features taken into account.

\section{Materials and methods}

The activity of $\alpha$-amylase was analyzed in the liver of the following species of Black Sea fish: scorpion fish Scorpaena porcus Linnaeus, 1758 (order Scorpaeniformes, fam- ily Scorpaenidae), stargazer Uranoscopus scaber Linnaeus, 1758 (ord. Peciformes, fam. Uranoscopidae), round goby Neogobius melanostomus (Pallas, 1814), knout goby Mesogobius batrachocephalus (Pallas, 1814) (ord. Perciformes, fam. Gobiidae), Mediterranean three-barbeled rockling Gaidropsarus mediterraneus (Linnaeus, 1758), whiting Merlangius merlangus euxinus (Nordmann, 1840) (ord. Gadiformes, fam. Gadidae), red mullet Mullus barbatus ponticus Essipov, 1927 (ord. Peciformes, fam. Mullidae), peacock wrasse Symphodus tinca (Linnaeus, 1758) (ord. Peciformes, fam. Labridae), golden grey mullet Chelon auratus (Risso, 1810) (ord. Mugiliformes, fam. Mugilidae), high body pickerel Spicara flexuosa Rafinesque, 1810 (ord. Perciformes, Sparidae), Mediterranean horse mackerel Trachurus mediteraneus (Steinedachner, 1868) (ord. Perciformes, Carangidae), and annular seabream Diplodus annularis (Linnaeus, 1758) (ord. Perciformes, fam. Sparidae).

The samples of fish were caught in Sevastopol bays (Fig. 1) from 2011 to 2014 using bottom snares (depth 18-20 m, net diameter - $12 \mathrm{~mm}$ ).

\section{Ethics Statement}

After being caught, the samples were kept in a large tank on the boat for $30 \mathrm{~min}$ before delivery to the laboratory. Then, they were placed into the aquarium (it was filled with water with artificial aeration taken from their natural habitat, a bay of the Black Sea) where they were kept for an hour. Each fish was quickly killed by cutting the spine, and the liver was immediately taken and frozen at $-20^{\circ} \mathrm{C}$. 


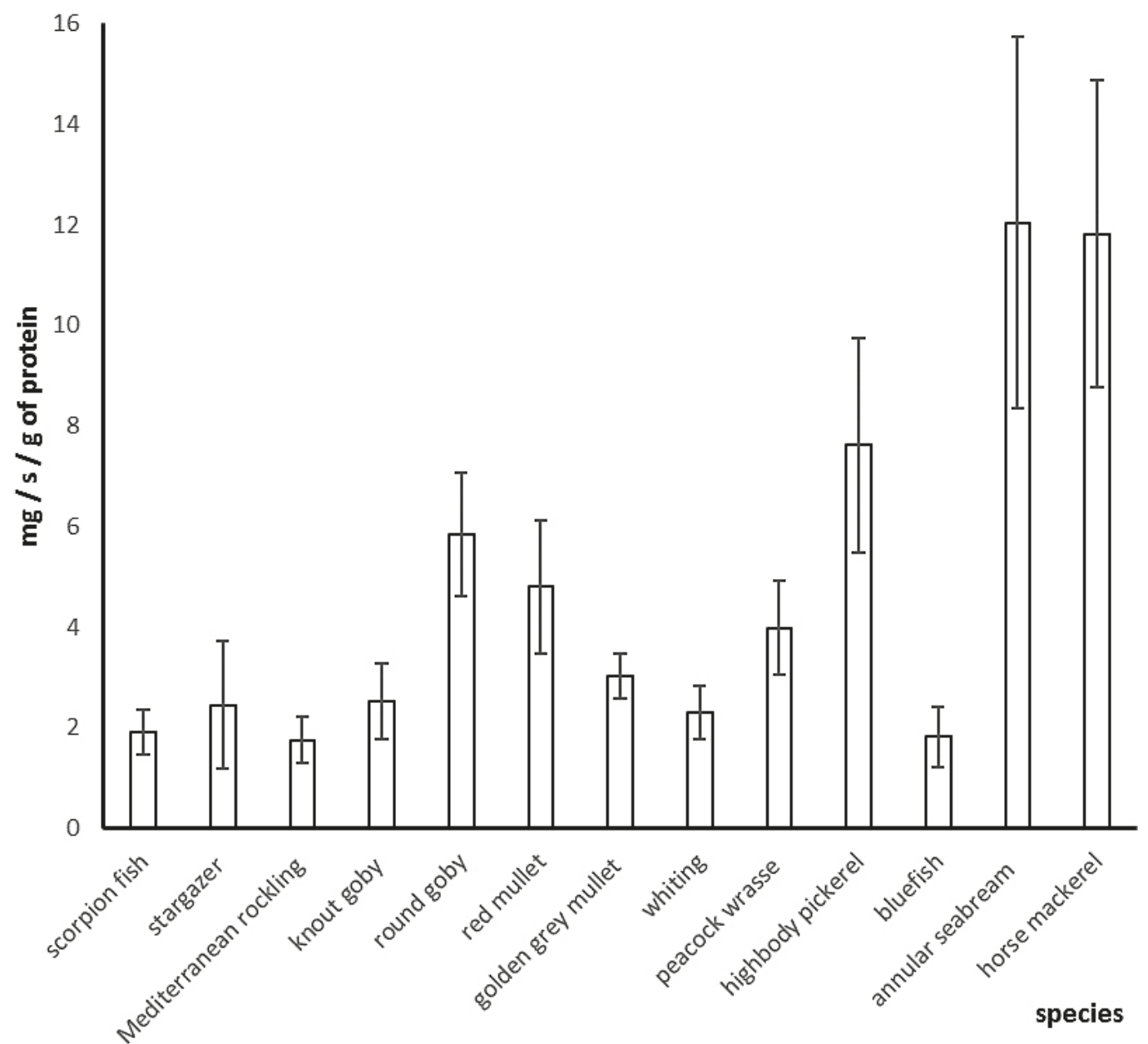

Fig. 2. The activity of a-amylase in the liver of different species of Black Sea fish from coastal area of Sevastopol $(\mathrm{M} \pm \mathrm{SEM})$.

The biological analysis of fish was performed in accordance with the standard ichthyologic techniques (Pravdin, 1966). Age was determined by using scales for high body pickerel, wrasse and golden grey mullet and for other fish - by using otoliths after their being kept in glycerin solution (50\%) for one week.

The enzyme activity was calculated in liver homogenates and presented in grams of protein.

The biochemical analysis, calculation of enzyme activity and the protein concentration in samples were performed in accordance with approved techniques (Pozdnyakova et al., 2009) by using a kit of reagents (Filisit, Ukraine, https://alvimedika.com.ua/uk/nabory-dljaklinicheskoy-biohimii/448-ooo-npp-filisit-diagnostikaukraina.html). The concentration of protein was determined in accordance with the Lowry method (Lowry et al., 1951). The activity of amylase in liver homogenates was analyzed using the Caraway method (Caraway, 1959) with a small modification (the whole procedure, including homogenates preparation, was carried out in the cold, without 5 minutes incubation of samples at $37^{\circ} \mathrm{C}$ ). This method is based on a change in the color intensity of the iodine-starch complex, which is proportional to the activity of the enzyme in the sample. The optical density of the samples was determined at $600 \mathrm{~nm}$ using the spectrophotometer Specol 211 (Carl, Zeiss).

The author cited data from the literature on the water and sea ground state and the biodiversity of some species of invertebrates (Kuzminova, 2006; Kuzminova, Dorokhova and Rudneva, 2014a) to describe the ecological status of the bays where fish were caught.

The results of biochemical analysis were statistically processed using the Mann-Whitney U-test (Mann and Whitney, 1947) with probability level $\mathrm{p} \geq 0.05$ and presented as $\mathrm{M} \pm \mathrm{SEM}$.

\section{Results}

The level of enzyme activity is very high only in the liver of annular seabream and horse mackerel (Fig. 2). Given the research data on food objects of the studied species, it can be supposed that the Black Sea carnivorous fish (scorpion fish, stargazers, shore rockling, whiting and bluefish) have a low level of enzyme activity when they 
Table. The activity of a-amylase in the liver of mass Black Sea fish from bays of Sevastopol with different ecological conditions ( $\mathrm{mg} / \mathrm{s} / \mathrm{g}$ of protein)

\begin{tabular}{|c|c|c|c|c|c|c|}
\hline Specie & Sex & $\begin{array}{c}\text { Balaklavskaya } \\
\text { Bay }\end{array}$ & $\begin{array}{c}\text { Karantinnaya } \\
\text { Bay }\end{array}$ & $\begin{array}{c}\text { Alexandrovskaya } \\
\text { Bay }\end{array}$ & $\begin{array}{l}\text { Cape } \\
\text { Tolsty }\end{array}$ & note \\
\hline \multirow[t]{2}{*}{ horse mackerel } & female & - & $\begin{array}{c}0.89 \pm 0.48 \\
N=6\end{array}$ & $\begin{array}{c}16.42 \pm 9.22 * * \\
N=11\end{array}$ & - & \multirow[t]{2}{*}{$\begin{array}{l}\text { age } 1-2 \text { y.o., different stages of } \\
\text { gonad maturing, mostly rest }\end{array}$} \\
\hline & male & $\begin{array}{c}3.49 \pm 1.68 \\
N=9\end{array}$ & $\begin{array}{c}32.22 \pm 11.68^{*} \\
N=7\end{array}$ & $\begin{array}{c}6.06 \pm 1.32 * \\
N=9\end{array}$ & - & \\
\hline \multirow[t]{2}{*}{ high body pickerel } & female & $\begin{array}{c}4.68 \pm 2.02 \\
N=3\end{array}$ & $\begin{array}{l}5.57 \pm 1.36 \\
N=20\end{array}$ & $\begin{array}{c}10.87 \pm 2.92 \\
N=11\end{array}$ & - & \multirow[t]{2}{*}{ age 2-3 y.o., rest } \\
\hline & male & $\begin{array}{l}5.78 \pm 1.72 \\
N=15\end{array}$ & $\begin{array}{l}4.41 \pm 0.99 \\
N=15\end{array}$ & $\begin{array}{c}2.03 \pm 0.89 \\
N=5\end{array}$ & & \\
\hline peacock wrasse & $\Sigma$ & - & $\begin{array}{c}3.48 \pm 1.72 \\
N=7\end{array}$ & $\begin{array}{c}4.13 \pm 1.11 \\
N=26\end{array}$ & - & $\begin{array}{l}\text { age } 2+-8 \text { y.o., different stages } \\
\text { of gonad maturing }\end{array}$ \\
\hline golden grey mullet & juvenile & $\begin{array}{c}3.32 \pm 0.56 \\
N=36\end{array}$ & $\begin{array}{l}1.73 \pm 1.11 \\
N=3\end{array}$ & $\begin{array}{l}2.29 \pm 0.84 \\
N=9\end{array}$ & - & age $2-5$ y.o. \\
\hline annular seabream & $\Sigma$ & $\begin{array}{c}8.02 \pm 2.26 \\
N=3\end{array}$ & $\begin{array}{l}15.30 \pm 8.21 \\
N=4\end{array}$ & $\begin{array}{l}11.96 \pm 5.31 \\
N=12\end{array}$ & - & age $1+-2+y .0 .$, rest \\
\hline \multirow[t]{2}{*}{ scorpion fish } & female & $\begin{array}{c}0.57 \pm 0.22 \\
N=13\end{array}$ & $\begin{array}{c}0.57 \pm 0.22 \\
N=8\end{array}$ & $\begin{array}{c}4.05 \pm 2.96 \\
N=13\end{array}$ & $\begin{array}{c}1.43 \pm 0.26 \\
N=8\end{array}$ & \multirow[t]{2}{*}{$\begin{array}{l}\text { age 3-6 y.o., different stages of } \\
\text { gonad maturing, mostly spawn }\end{array}$} \\
\hline & male & $\begin{array}{l}0.94 \pm 0.26 \\
N=6\end{array}$ & $\begin{array}{c}0.94 \pm 0.26 \\
N=12\end{array}$ & $\begin{array}{c}1.22 \pm 0.29 \\
N=13\end{array}$ & $\begin{array}{c}1.49 \pm 0.49 \\
N=8\end{array}$ & \\
\hline round goby & $\Sigma$ & - & $\begin{array}{l}5.57 \pm 1.07 \\
N=8\end{array}$ & $\begin{array}{l}6.29 \pm 2.91 \\
N=5\end{array}$ & - & age 2-4 y.o., spawn \\
\hline knout goby & $\Sigma$ & - & $\begin{array}{l}4.22 \pm 2.00 \\
N=6\end{array}$ & $\begin{array}{c}1.65 \pm 0.64 \\
N=13\end{array}$ & - & $\begin{array}{l}\text { age } 2+-4 \text { y.o., different stages } \\
\text { of gonad maturing mostly } \\
\text { spawn }\end{array}$ \\
\hline \multirow[t]{2}{*}{$\begin{array}{l}\text { Mediterranean three- } \\
\text { barbeled rockling }\end{array}$} & female & - & $\begin{array}{c}1.66 \pm 0.64 \\
N=5\end{array}$ & $\begin{array}{c}1.35 \pm 0.71 \\
N=11\end{array}$ & - & \multirow[t]{2}{*}{ age $1+-3$ y.o., spawn } \\
\hline & male & - & $\begin{array}{l}3.17 \pm 1.77 \\
N=5\end{array}$ & $\begin{array}{l}0.69 \pm 0.32 \\
N=6\end{array}$ & - & \\
\hline
\end{tabular}

Note: values in italics mean significant differences between male and female, * — significant differences with fish from Balaklavskaya Bay, ** — significant differences with fish from Karantinnaya Bay.

live on a diet of fish. In the liver of golden grey mullet, which has a mixed type of food, amylase activity is at a medium level. Gobies and peacock wrasse feed mainly on shellfish, with the result that they have a higher enzyme activity level than the species mentioned above. Omnivorous fish such as annular seabream and horse mackerel, whose dietary preference is crustaceans, have the maximum level of $\alpha$-amylase activity. Significant differences $(\mathrm{p} \leq 0.05)$ were found between fish from these two groups - those with common food sources and typical carnivorous fish - as follows, the enzyme activity in horse mackerel significantly differs from that in scorpion fish, knout gobies, three-barbeled rockling, whiting and peacock wrasse $(\mathrm{p} \leq 0.05)$. The enzyme activity in the liver of annual seabream is significantly different from that in scorpion fish, knout gobies, three-barbeled rockling, whiting and peacock wrasse $(\mathrm{p} \leq 0.05)$. In addition, significant differences were obtained for such species: scorpion fish - with knout gobies and peacock wrasse; round gobies - with knout gobies, three-barbeled rockling, whiting and golden grey mullet; red mullet — with knout gobies and whiting, which also differ in food source.

The data on the values of enzyme in females and males of different species are presented in Table 1 with catch points taken into account. Insignificant sex differences were found for species registered and for individuals from all areas for both females and males. That the enzyme activity level is higher for females than males is true only for high body pickerel from Alexandrovskaya Bay. No differences in amylase activity between specimens of both males and females were found for knout gobies from Alexandrovskaya Bay (in females, liver activity was $1.15 \pm 0.26 \mathrm{mg} / \mathrm{s} / \mathrm{g}$ of protein, in male livers $2.24 \pm 1.38 \mathrm{mg} / \mathrm{s} / \mathrm{g}$ of protein), nor were they found for whiting liver from Karantinnaya Bay (female enzyme activity was $2.36 \pm 0.66 \mathrm{mg} / \mathrm{s} / \mathrm{g}$ of protein, males $-3.12 \pm$ $1.65 \mathrm{mg} / \mathrm{s} / \mathrm{g}$ of protein). 

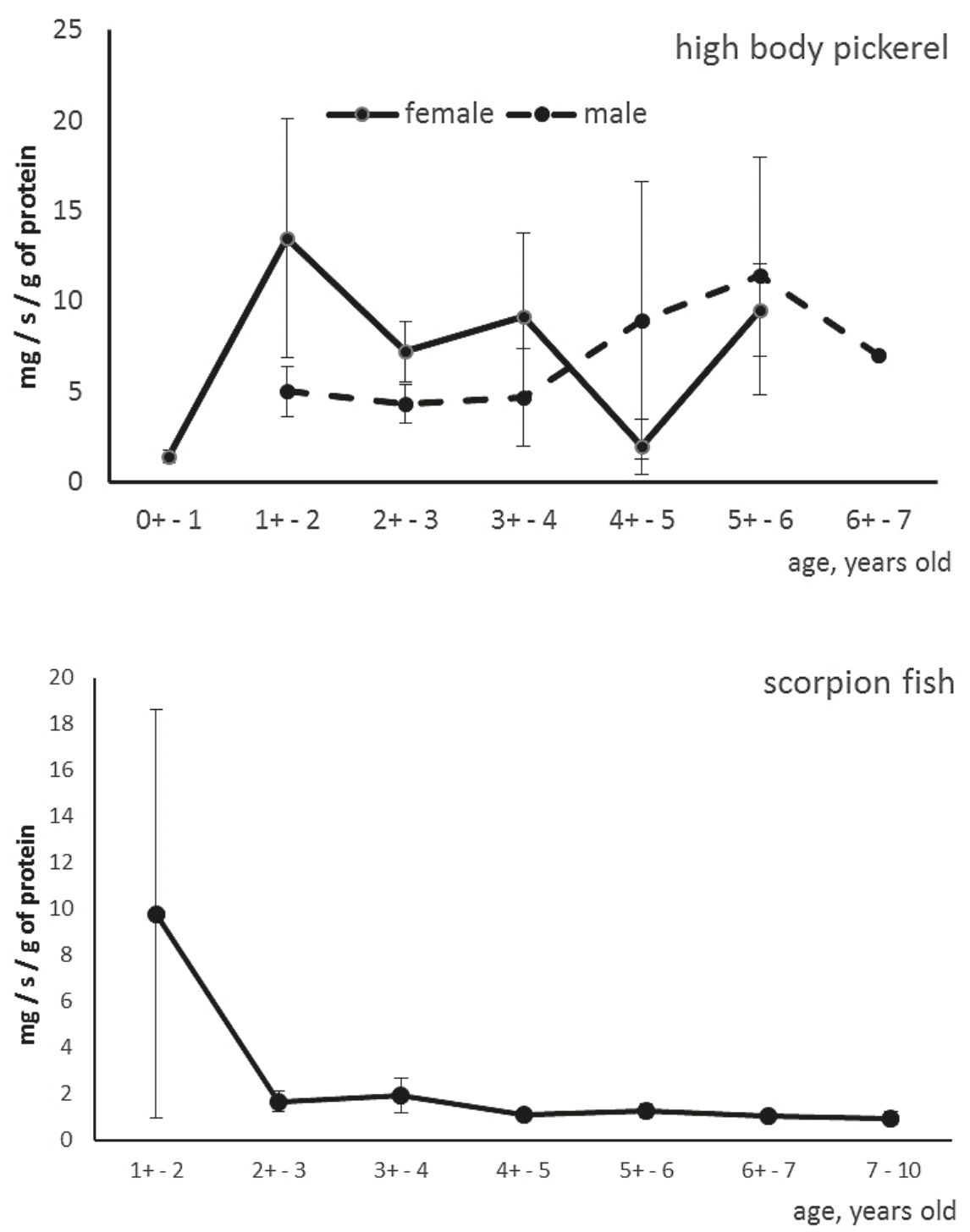

Fig. 3. The activity of a-amylase in the liver of high body pickerel and scorpion fish of different ages $(\mathrm{M} \pm \mathrm{SEM})$.

Due to the fact that differences in the activity of alpha-amylase in the liver of high body pickerel between the samples from different bays were insignificant, but there were considerable differences between individuals of both sexes, the enzyme activity for individuals of different ages was calculated (Fig. 3). It was found that enzyme activity is of the same level in all the specimens, irrespective of age (both females and males). Lack of any connection between enzyme activity and age is also characteristic of scorpion fish, but that does not apply to very young specimens: they had a high activity level. Significant differences $(0.01 \leq \mathrm{p} \leq 0.05)$ were found only between very young and middle age groups for Scorpaena porcus and Spicara flexuosa.

The analysis of seasonal effects on enzyme activity in the liver of S. porcus and S. flexuosa has revealed that enzyme activity is lower in winter than in other seasons
(Fig. 4), but the seasonal differences are insignificant for scorpion fish, and only between spring and autumn in the liver of high body pickerel (despite close middle values of enzyme activity).

\section{Discussion}

There is some evidence that benthophages feeding on detritus have the minimum amylase activity level, while the fish feeding on mollusks and macrophyte have a higher level, and the maximum level of studied enzyme activity is in fish that consume food rich in carbohydrates (Ugolev and Kuzmina, 1993). However, the authors pointed out that greatest differences have been found within the group of the same species, especially for $\alpha$-amylase. Biochemical analysis of digestive enzymes of Black Sea fish has revealed that the level of total 


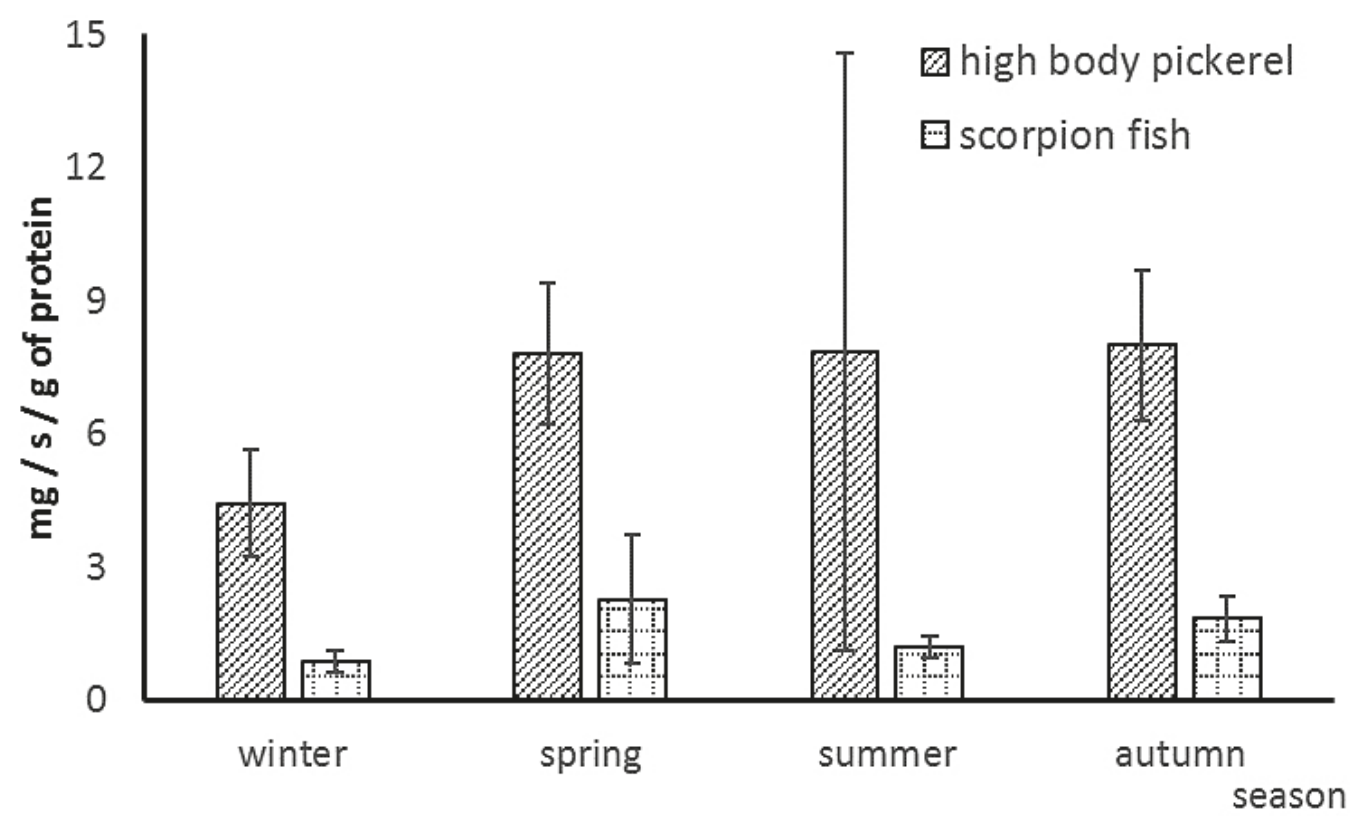

Fig. 4. The activity of a-amylase in the liver of high body pickerel and scorpion fish in different seasons (M $\pm S E M)$.

amylolytic and sucrose activity in mucosal homogenates of whiting was minimum $\left(0.7\right.$ and $0.1 \mu \mathrm{mol}^{*} \mathrm{gmol}^{\star} \mathrm{g}-1^{*}$ min-1), and for annular seabream (like in our study) the value was maximum $\left(4.1\right.$ and $3.9 \mu \mathrm{mol}{ }^{*} \mathrm{gmol}{ }^{*} \mathrm{~g}-1{ }^{*}$ min-1) (Ugolev, 1993). The results obtained are consistent with available data that the enzyme is primarily produced in fish feeding on plant objects (Fernández, Moyano, Díaz and Martínez, 2001). The facts that the activity of this enzyme is dependent on the diet and ecological groups of fish; and the ratio of membrane activity to abdominal activity of amylase is greater for predatory fish than for herbivorous (reviewed by (Kuzmina, 1977). It is also known that the activity of digestive enzymes in the intestines of omnivorous fish is the greatest (Hidalgo, Urea and Sanz, 1999; Al-Tameemi, Aldubaikul and Salman, 2010; Gottlieb et al., 2018). This is true in our case in regard to horse mackerel, annual seabream, round goby, peacock wrasse, and red mullet, which have a wide food spectrum.

There are very few articles devoted to the identification of sex differences in the studied enzyme, in particular in fish. The study of $\alpha$-amylase activity in the urine of manatees Trichechus inunguis (Pantoja, Rosas, Da Silva and Dos Santos, 2010) did not reveal differences between males and females. Nor were they found in the intestinal mucosa of bream from different pre-spawning groups caught in the river Sit (Ugolev and Kuzmina, 1993). However, in the blood of rainbow trout Oncorhynchus mykiss farmed in Iran, the enzyme activity level was higher in males than in females (Yousefian et al., 2010). Our results are probably connected with the absence of sexual difference between adult male and female food preferences (Rafrafi-Nouira et al., 2016).
To my mind, the most likely explanation of the lack of significant differences in activity of alpha-amylase in the liver of fish from different bays lies in the fact that the environmental conditions of the Black Sea have been improving since 2008, compared with those of the late 1990s (Zavyalov et al., 2016). This improvement was expressed in a decrease in the level of petroleum hydrocarbons in bottom sediments (Mironov and Alemov, 2018), an increase in species diversity and zoobenthos biomass (Revkov, 2011; Alyomov et al., 2015) and, as a result of this, an increase in the number, size and weight of adult fish and an improvement in the food base of ichthyoplankton (Oven, Salekhova and Kuz'minova, 2008; Vdodovich, 2008; Klimova, 2010; Zavyalov et al., 2016). Therefore, the state of food source base in different locations can be similar.

However, deterioration in environmental conditions might lead to a situation in which the enzyme investigated in different biological materials might either be intensively synthesized or inhibited. For instance, the mass death of common carp Cyprinus carpio, chub Leuciscus cephalus, trout barb Capoeta trutta and tigris scraper Capoeta capoeta umbla ocurred in the Turkish dam lake because of low oxygen concentration, which was provoked by an excessive level of nitrogen, copper and nickel compounds in wastewater dumped into the lake. In addition, $\alpha$-amylase activity in the serum of normal individuals of fish and at the time of death increased (SSevket Kandemir et al., 2010). Under the influence of different concentrations of diesel fuel, the activity of alpha-amylase in red clover (Trifolium pratense L.) decreased, which has a negative effect on seed growth. The author believes this effect is caused by a decrease in wa- 
ter absorption, which leads to low conversion of starch (Tonel et al., 2013).

In periodicals, the data on the relationship between amylase activity and age are fragmentary. Based on the findings of different scientists on crustaceans and shellfish, and on his own research results about clam Pholas orientalis, R. U. Tizon et al. suggested that the lack of connection between enzyme activity and size is due to the variability of individual animals' "digestive responses" (Tizon, Serrano and Traifalgar, 2013). However, there are some data in agreement with our results: the total amylolytic activity in juvenile pike, perch, roach, and bream was significantly higher than that of adult fish, especially when the sort of food changes during a transition to predatory lifestyle (Ugolev and Kuzmina, 1993; Kuz'mina, 1996). A similar research aspect was described for Indian carp Labeo rohita; it was found that the activity of amylase exhibited an increasing trend with size up to the middle size group, decreasing thereafter (Umalatha, Sridhar, Kushwaha and Gangadhar, 2016). In addition, Munilla-Moran et al. found that amylase activity decreased with age: 3 -day-old larvae of turbot Scophthalmus maximus (L.) and 30-day-old juveniles were compared with adults (Munilla-Moran and Stark, 1990).

A very interesting biological phenomenon is that for fish and aquatic mammals there is a difference in amylase activity only between newborn (hatched prelarvae fish and juveniles) and adult individuals, but within different-sized groups of mature specimens amylase "works" smoothly. The researchers put forward a reason why the food source at the early stages of development is different from the food source of adult organisms: there is a high need for amylase for digestion of phytoplankton or consuming yolk sac/milk, but later, after the complete formation of the digestive tract and transition to quite a monotonous diet, the enzyme activity is quite stable (Tovar-Ramírez et al., 2004; Alvarez-González et al., 2006; Pantoja, Rosas, Da Silva and Dos Santos, 2010; Farhoudi, Abedian Kenari, Nazari and Mackhdoomi, 2013). A. M. Ugolev and V. V. Kuzmina (1993) found that the age dynamic of enzymatic activity for carnivorous species, as optional benthophages, is less pronounced than for omnivorous species, which is in agreement with our own results obtained for high body pickerel and scorpion fish. The authors reported that the tendency for activity to decrease with age was noticed for the intestinal mucosa of perch, roach and bream (Ugolev and Kuzmina, 1993; Kuzmina, 1996).

It is known that the production of pancreatic amylase in freshwater fish is greatest in summer (Kuzmina, 1977; Ugolev and Kuzmina, 1993; Kuz'mina, Golovanova and Izvekova, 1996). The explanation for this is that fish have maximal enzymatic activity in the period of most active eating (Ugolev and Kuzmina, 1993), which, undoubtedly, can be applied to Black Sea fish. Some authors have added that digestive enzyme activity depends on food availability and variability, and that is more expressed in summer (Gottlieb et al., 2018). In the case of high body pickerel and scorpion fish, having low amylase activity only in winter, it can also be explained by this reason, because even in autumn the Black Sea remains warm, so marine fish have an adequate food supply.

Thus, analysis of $\alpha$-amylase activity in the liver of habitual species of Black Sea fish showed:

- the level of enzyme activity is very high only in the liver of annular seabream and horsemackerel, having a wide food spectrum (limits from 1.82 to $69.16 \mathrm{mg} / \mathrm{s} / \mathrm{g}$ of protein);

- enzyme activity studied is lower in winter than in other seasons because of less active eating;

- its value does not depend on the sex and age of adult fish;

- the parameter studied does not have significant differences between its values obtained when studying the liver of fish from different bays.

\section{Acknowledgments}

The authors would like to thank the fishing crew of the Institute of Biology of the Southern Seas of RAS and the fishing team Kolkhoz imeni Lenina from Balaklavskaya Bay for fish provided as research material.

The work was carried out on the state theme of the IBSS "Molismological and Biogeochemical Basis of the Homeostasis of Marine Ecosystems" (№ 0828-2019-0006) (registration number: AAAA-A18-118020890090-2).

\section{References}

Afanasyeva, O. M. 2011. The assessment of zoohygienic safety of monklavity-1 and its use for calves growing. Author. Dis. Cand. Thesis. Veterinary sanitation, ecology, pet hygiene and veterinary sanitary expertise. Saint Petersburg. 20 p. (In Russian)

Alarcon, F. J., Martínnez, T. F., Díaz, M., and Moyano, F. J. 2001. Characterization of digestive carbohydrase activity in the gilthead seabream (Sparus aurata). Hydrobiologia 445:199-204. https://doi.org/10.1023/A:1017521900442

Alyomov, S. V., Guseva, E. V., Solov'yova, O. V., Tihonova, E. A., Burdiyan, N. V., and Doroshenko, Yu. V. 2015. The results of complex sanitary-biological studies of Pesochnaya bay (Sevastopol region). Scientific notes of the Crimean state university V. I. Vernadskogo named. "Biology, Chemistry» 67(2):3-17. (In Russian)

Alvarez-González, C.A., Cervantes-Trujano, M., TovarRamirez, D., Conklin, D. E., Nolasko, H., Gisbert, E., and Piedrahita, R. 2006. Development of digestive enzymes in California halibut Paralichthys californicus larvae. Fish Physiology and Biochemistry 31:83-93. https://doi. org/10.1007/s10695-006-0003-8

Al-Tameemi, R., Aldubaikul, A., and Salman, N. A. 2010. Comparative study of a-amylase activity in three Cyprinid species of different feeding habits from Southern Iraq. Turkish Journal of Fisheries and Aquatic Sciences 10:411-414. https://doi.org/10.4194/trjfas.2010.0315 
Caraway, W. T. 1959. A stable starch substrate for the determination of amylase in serum and other body fluids. American Journal Clinical Pathologic 32:97-99. https://doi. org/10.1093/ajcp/32.1_ts.97

Farhoudi, A., Abedian Kenari, A. M., Nazari, R. M., and Mackhdoomi, C. H. 2013. Changes of digestive enzymes of activity in common carp (Cyprinus carpio) during larval ontogeny. Iranian journal of Fisheries Sciences 12 (2):320334.

Fernández, I., Moyano, F. J., Díaz, M., and Martínez, T. 2001. Characterization of a-amylase activity in five species of Mediterranean sparid fishes Sparidae, Teleostei. Journal of Experimental Marine Biology and Ecology 262:1-12. https://doi.org/10.1016/S0022-0981(01)00228-3

Ferreira, C. M., Field, C. L., and Tuttle, A. D. 2010. Hematological and plasma biochemical parameters of aquariummaintained cownose rays. Journal of Aquatic Animal Health 22:123-128. https://doi.org/10.1577/H09-048.1

Gisbert, E., Giménez, G., Fernández, I., Kotzamanis, Y., and Estévez, A. 2009. Development of digestive enzymes in common dentex Dentex dentex during early ontogeny. Aquaculture 287:381-387. https://doi.org/10.1016/j. aquaculture.2008.10.039

Gottlieb Almeida, A.P., Zardo, E. L., Toni, C., Behr, E. R., da Silva, L. P., Vieira, J.P., Loro, V. L., and Baldisserotto, B. 2018. Composition of gastrointestinal content, protease and lipase activities in summer and winter of four freshwater siluriforms (Teleostei: Actinopterygii) with two different feeding habits. Zoologia 35:e13286 https://doi. org/10.3897/zoologia.35.e13286

Hidalgo, M. C., Urea, E., and Sanz, A. 1999. Comparative study of digestive enzymes in fish with different nutritional habits. Proteolytic and amylase activities. Aquaculture 170:267-283. https://doi.org/10.1016/S00448486(98)00413-X

Kandyuk, R. P. 1966. Comparative study of the activity and the thermal stability of digestive enzymes of plankton and benthic fish northwestern part of the Black Sea. Author. Diss. Thesis. Odessa. Hydrobiology. 22 p. (In Russian)

Klimova, T. N. 2010. Ichthyoplankton of the coastal waters of south-western Crimea in 2002-2008. Marine ecological journal IX(1):39-52. (In Russian)

Krogdahl, A., Hemre, G. I., and Mommsen, T. P. 2005. Carbohydrates in fish nutrition: digestion and absorption in postlarval stages. Aquaculture Nutrition 11(2):103-122. https://doi.org/10.1111/j.1365-2095.2004.00327.x

Kuzmina, V. V. 1977. Features of membrane digestion of freshwater bony fish. Journal of Ichthyology 17(1):111-119. (In Russian)

Kuz'mina, V. V. 1996. Influence of age on digestive enzyme activity in some freshwater teleosts. Aquaculture 148:25-37. https://doi.org/10.1016/S0044-8486(96)01370-1

Kuz'mina,V. V., Golovanova, I. L., and Izvekova, G. I. 1996. Influence of temperature and season on some characteristics of intestinal mucosa carbohydrases in six freshwater fishes. Comparative Biochemistry and Physiology Part B: Biochemistry and Molecular Biology 113:255-260. https://doi.org/10.1016/0305-0491(95)02019-5

Kuzminova, N. S. 2006. Study of the toxic effect of domestic sewage on marine organisms. Diss. Cand. Thesis. Ecology. Moscow. 168 p. (In Russian)

Kuzminova, N.S. 2010. Species and ecological characteristics of lysozyme activity in the serum of some species of Black Sea fish. Ecological systems and devices 2:22-27. (In Russian)

Kuzminova, N., Dorokhova, I., and Rudneva, I. 2014a. Agedependent changes of Mediterranean Trachurus mediterraneus male and female from coastal waters of Sevastopol (Black Sea, Ukraine). Turkish Journal of Fisheries and Aquatic Sciences 14:183-192. https://doi. org/10.4194/1303-2712-v14_1_20

Kuzminova, N.S., Kulakovskaya, E. V., and Yakimova, K. V. $2014 \mathrm{~b}$. The concentration of circulating immune complexes in the blood of Black Sea fishes in the modern period; pp. 321-325 in Abstracts of Intern. scientific conf. «Actual problems of fisheries and aquaculture for basins of the southern seas of Russia». Rostov-on-Don, 1-3 October 2014. (In Russian)

Kuzminova, N.S. 2016. Dependence of alkaline phosphatase activity on bioecological parameters of Black Sea fish. Journal of Ichthyology 56(2):298-303. https://doi. org/10.1134/S0032945216020089

Lowry, O.H., Rosbrough, N. J., Farr, A.L., and Randall, R. J. 1951. Protein measurement with the Folin phenol reagent. The Journal of Biological Chemistry 193:265-275.

Mann, H. B. and Whitney, D. R. 1947. On a test of whether one of 2 random variables is stochastically larger than the other. Annals of Mathematical Statistics 18:50-60. https:// doi.org/10.1214/aoms/1177730491

Mironov, O. G. and Alemov, S. V. 2018. Sanitary and biological research of coastal water areas of south-western Crimea at the beginning of the XXI century. Institut morskih biologicheskih issledovanij im. A. O. Kovalevskogo RAN, Izdatelstvo IT «AREAL», Simferopol. 276 p. (In Russian)

Moreau, Y., Desseaux, V., Koukiekolo, R., Marchis-Mouren, G., and Santimone, M. 2001. Starch digestion in tropical fishes: isolation, structural studies and inhibition kinetics of alpha-amylases from two tilapias Oreochromis niloticus and Sarotherodon melanotheron. Comparative Biochemistry and Physiology Part B: Biochemistry and Molecular Biology 128:543-552. https://doi.org/10.1016/S1096-4959(00)00358-4

Munilla-Moran, R., Stark, J. R. 1990. Metabolism in marine flatfish. VI. Effect of nutritional state on digestion in turbot, Scophthalmus maximus (L.). Comparative Biochemistry and Physiology Part B: Comparative Biochemistry 95:625-634. https://doi.org/10.1016/0305-0491(90)90032-O

Oven, L. S., Salekhova, L. P., and Kuz'minova, N. S. 2008. Longterm dynamics of the species composition and abundance of Black Sea fish in the region of Sevastopol. Fisheries in Ukraine 4(57):15-18. (In Russian)

Pantoja, T. M. A., Rosas, F. C. W., Da Silva, V. M. F., and Dos Santos, A. M. F. 2010. Urinary parameters of Trichechus inunguis (Mammalia, Sirenia): reference values for the Amazonian Manatee. Brazilian Journal of Biology 70(3):607-615. https://doi.org/10.1590/S1519-69842010000300018

Pozdnyakova, I. A., Ivanov, V. V., Kanskaya, N. V., Timin, O. A., and Kolesova, N. I. 2009. Laboratory workshop on biological chemistry for students of Faculty of Pharmacy: Tutorial. Izdatelstvo Siberian State Medical University, Tomsk. 250 p. (In Russian)

Pravdin, I. F. 1966. Guidelines for the study of fish. Izdatelstvo Pishevaya promislennost, Moscow. 374 p. (In Russian)

Rafrafi-Nouira, S., Kamel-Moutalibi, O. El., Boumaïza, M., and Capapé, C. 2016. Food and feeding habits of black scorpionfish, Scorpaena porcus (Osteichthyes: Scorpaenidae) from Northern coast of Tunisia (Central Mediterranean). Journal of Ichthyology 56(1):107-123. https://doi. org/10.1134/S0032945216010112

Revkov, N. K. 2011. Macrozoobenthos of the Ukrainian shelf of the Black Sea; pp. 140-162 in V. N. Eremeev, A. V. Gaevskaya, G. E. Shul'man, Yu. A. Zagorodnyaya (ed.): Promyslovye bioresursy Chernogo i Azovskogo morej. NAN Ukrainy, Institut biologii yuzhnyh morej NAN Ukrainy. Izdatelstvo EKOSI-Gidrofizika, Sevastopol. (In Russian)

Rudneva, I. I., Kuzminova, N.S., Skuratovskaya, E. N., and Kovyrshina, T. B. 2010. Age composition and antioxidant 
enzyme activities in blood of Black Sea teleosts. Comparative Biochemistry and Physiology Part C: Toxicology \& Pharmacology 151(2):229-239. https://doi.org/10.1016/j. cbpc.2009.11.001

Sadhu, N., Sharma, S. R. K., Joseph, S., Dube, P., and Philipose, K. K. 2014. Chronic stress due to high stocking density in open sea cage farming induces variation in biochemical and immunological functions in Asian seabass (Lates calcarifer, Bloch). Fish Physiology and Biochemistry 40(4):1105-1113. https://doi.org/10.1007/s10695-0149909-8

Şevket Kandemir, S., Örün, İ, Talas, Z., Örün, G. N., Erdoğan, K., Işık, M., Altaş, L., and Duran, A. 2010. Effects on mortality of biochemical and limnological properties on some fish species in Sultansuyu Dam Lake (Malatya), Turkey. Turkish Journal of Fisheries and Aquatic Sciences 10:431-437. https://doi.org/10.4194/trjfas.2010.0318

Tizon, R. U., Serrano, A. E., and Traifalgar, Jr. R. F. M. 2013. Influence of size on digestive enzyme activities in the Angelwing clam Pholasorientalis. European Journal of Experimental Biology 3(1):602-607.

Tonel, F. R., Marini, P., Moraes, C. L., de Magalhães Bandeira, J., Baudet Labbé, L. M., Villela, F. A., and de Moraes, D. M. 2013. Physiological and biochemical changes in seeds and seedlings of redclover submitted to diesel oil. IHERINGIA, Série Botânica, Porto Alegre 68(2):195-201.

Tovar-Ramírez, D., Zambonito Infante, J., Cahu, C., Gatesoupe, F.J., and Vázquez-Juárez, R. 2004. Influence of dietary live yeast on European sea bass (Dicentrarchus labrax) larval development. Aquaculture 234:415-427. https://doi.org/10.1016/j.aquaculture.2004.01.028

Ugolev, A. M. and Kuzmina, V. V. 1993. Digestive processes and the adaptation of fish. Izdatelstvo Gidrometeoizdat, Saint Petersburg. 120 p. (In Russian)
Vdodovich, I. V. 2008. Nutrition of the larvae of the Black Sea gobies in the coastal waters of Sevastopol in the summer period based on materials from 2003-2009. Ecology of the sea 76:40-44. (In Russian)

Vinnikova, S. V. 2010. Membrane digestion in rabbits under stress conditions and its correction. Author. Diss. Cand. Thesis. Diagnosis of diseases and therapy of animals, pathology, oncology and morphology of animals. Saint Petersburg. 25 p. (In Russian)

Umalatha, S. N., Kushwaha J. P., and Gangadhar, B. 2016. Digestive enzyme activities in different size groups and segments of the digestive tract in Labeo rohita (Day, 1878). Journal of Aquaculture and Marine Biology 4(5):00098. https://doi.org/10.15406/jamb.2016.04.00098

Yousefian, M., Sheikholeslami, A., Hedayatifard, M., Dehpour, A. A., Fazli, H., Chiaci, M., Farabi, S. V., and Najafpour, S. H. 2010. Serum biochemical parameters of male and female rainbow trout (Oncorhynchus mykiss) cultured in Haraz River, Iran. World Journal of Island Marine Science 2(6):513-518.

Zacarias-Soto, M., Barón-Sevilla, B., and Lazo, J.P. 2013. Ontogeny and distribution of alkaline and acid phosphatase in the digestive system of California halibut larvae (Paralichthys californicus). Fish Physiology and Biochemistry 39:1331-1339. https://doi.org/10.1007.s10695-0139787-5

Zavyalov, A. V., Zalevskaya, I. N., Kovirshina, N. V., Kuzminova, N. S., Oven, L. S., Omelchenko, S. O., Poduvay, Y. V., Salekhova, L. P., Samotoy, Y. V., Skuratovskaya, E. N., Chesnokova, I.I., Shaida, V.G., and Shevchenko, N. F. 2016. Ecotoxicological studies of the coastal Black Sea ichthyofauna in the region of Sevastopol. Izdatelstvo GEOS, Moscow. 316 p. (In Russian) 